\title{
Bleomycin in the Treatment of Keloids and Hypertrophic Scars by Multiple Needle Punctures
}

\author{
Agustín España, MD, Teresa Solano, MD, and Emilio Quintanilla, MD \\ Department of Dermatology, University Clinic of Navarra, School of Medicine, \\ University of Navarra, Navarra, Spain
}

Background. The treatment of keloids and hypertrophic scars has been difficult and a recent French study showed that bleomycin has been useful in the treatment of these lesions.

Objective. To determine the effectiveness and safety of bleomycin in the treatment of hypertrophic scars and keloids when this drug is administered through multiple superficial punctures.

Methods. We applied bleomycin to keloids and hypertrophic scars in 13 patients using a multiple-puncture method on the surface of the skin. All patients were given bleomycin at a concentration of $1.5 \mathrm{IU} / \mathrm{ml}$. Clinical response after treatment was classified according to the following scale: complete flattening (100\%), highly significant flattening (>90\%), or significant flattening (75-90\%).

Results. The clinical response was very positive in all cases: complete flattening in six cases, highly significant flattening in six cases, and significant flattening in one case. Two patients presented a recurrence as a small nodule 10 and 12 months after the last infiltration.

Conclusions. These clinical findings show that administration of bleomycin in keloids and hypertrophic scars shows promise and needs further investigation.

A. España, MD, T. Solano, MD, and E. Quintanilla, MD have indicated no significant interest with commercial supporters.

Address correspondence and reprint requests to: Agustín España, MD, Department of Dermatology, School of Medicine, University Clinic of Navarra, University of Navarra, PO Box 4209, E-31080, Pamplona, Navarra, Spain, or e-mail: aespana@unav.es. 
Keloids and hypertrophic scars are two kinds of abnormal scar formation in the skin. ${ }^{1-3}$ At the present time, the mechanism that causes them is not fully understood, but it is thought to involve local histologic factors in connection with a hereditary component in most cases. Today there are many ways of treating these conditions with different responses. ${ }^{1-3}$ Corticosteroids administered intralesionally have been useful in keloids and hypertrophic scars. Topically applied silicones or gel sheets are sometimes a good treatment. Other treatments include cryotherapy alone or in combination with intralesional corticosteroids, intralesional 5-fluorouracil (5-FU), interferons, surgery, and lasers. Recently a French study in 36 patients showed that bleomycin can be useful for these lesions. However, these procedures sometimes pose therapeutic problems: (1) the forms of treatment available at present are not effective in all cases; (2) their use is long term and sometimes lesions reappear when treatment is suspended; and (3) the recommended treatment occasionally requires very aggressive measures that are quite disproportionate to the benign character of the lesions.

In this study we present our experience of treating 13 patients with keloids or hypertrophic scars with bleomycin. In all cases the lesions cleared completely or almost completely. To this we must add that the drug is easy to administer, moderately priced, and almost free of side effects.

\section{MATERIALS AND METHODS}

In this study we included 13 patients, 10 female and 3 male, ages $14-36$ years. In three cases the lesions were on the shoulder, one on the back, three in the presternal region, four at various different sites, one on the chin, and one on the face (Figures 1-3). In all cases the lesions were accompanied by local pruritus. The lesions had been present for 2 months to several years, and were secondary to surgery (five patients), of spontaneous origin (three patients), caused by vaccination (two patients) or by acne (two patients), or the result of accidental cuts (one patient) (Table 1). In seven of the patients no previous treatment had been given. All patients gave verbal consent before we used bleomycin, and female patients were warned not to become pregnant during treatment.

We analyzed the Fitzpatrick skin type in each patient. ${ }^{4}$ We followed other authors ${ }^{5}$ in our definitions of hypertrophic scars and keloids: hypertrophic scars can flatten spontaneously in the course of one or several years; keloids persist and may even extend beyond the site of the original injury.

The same method was used in all 13 patients. First, the lesion was anesthetized with intralesional $2 \%$ mepivacaine injection. After that the bleomycin was dripped onto the lesion, and then multiple punctures were made on the lesions by means of a syringe and a 25-gauge 5/8 $0.5 \times 16$ needle. This technique is different than that used by Shelley and Shelley; ${ }^{6}$ these authors first drizzled the bleomycin solution onto the wart and then punctured it with a bifurcated beveled vaccination needle. Our technique ensured that only a very small quantity of bleomycin penetrated into the lesion. In each case the maximum dose applied was $2 \mathrm{~cm}^{3} / \mathrm{cm}^{2}$ of skin treated, at a concentration of $1.5 \mathrm{IU} / \mathrm{ml}$, and a maximum of $6 \mathrm{~cm}^{3}$ of bleomycin was given per session. We used a pattern of 40 punctures $/ 5 \mathrm{~mm}^{2}$.

Sessions were held 1-4 months apart. At the present time, one to five sessions have been given to different patients (Table 1). The number of sessions was established for each patient depending on the cosmetic and functional posttreatment situations. Each patient was assessed before bleomycin treatment for four clinical points by anamnesis 
and clinical examination: size, symptomatic improvement, color, and thickness of keloids or hypertrophic scars. In addition, other side effects such as hepatic dysfunction were evaluated after four sessions of bleomycin by hepatic biochemistry. The information was recorded in the medical records. In all cases the following scale for assessing the results of treatment was used at the end of treatment: complete flattening of the lesion $(100 \%)$, highly significant flattening $(>90 \%)$, or significant flattening $(75-$ $90 \%$ ). We defined recurrence as local relapsing in patients who had obtained previous complete flattening. We explain side effects and the time of recurrence in the Results section. All patients were evaluated by the same person (A.E.).

\section{RESULTS}

The results of the 13 patients are shown in Table 1. Six of them presented hypertrophic scars and seven presented keloids. Four patients were skin type II and nine patients were skin type III.

In all patients, pruritus disappeared after the first session. No side effects, except slight residual pigmentation in two patients with skin type III (patients 2 and 8), were observed. In seven patients, treatment was concluded after complete flattening had been achieved (patients 1-4, 8, 11, and 13) (53.8\%) after 2, 5, 3, 3, 4, 1, and 3 sessions, respectively (Figure 1B). Four of the seven patients had hypertrophic scars and three had keloids. Two of the three patients with keloids (patients 2 and 8; Figure 2B) presented with a small nodule 12 and 10 months, respectively, after the last infiltration. The other complete flattening patients have so far presented no recurrence of the lesion and are stable 11 months and 3 years after bleomycin treatment. Highly significant flattening (>90\%) was achieved in another five patients (patients 6, 7, 9, 10, and 12) $(38.4 \%)$ (Figure 3B) and has endured for 5 months-2 years. Four of these five patients had keloids and only one had hypertrophic scars. In one patient we obtained significant flattening (patient 5); the patient found this to be aesthetically satisfactory and decided to discontinue treatment. This improvement is stable 8 months after treatment. This patient had hypertrophic scars (Table 1).

\section{DISCUSSION}

Hypertrophic scars and keloids are abnormal growths of the connective tissue secondary to trauma of the skin, the origin of which is usually apparent. While in the latter the connective tissue spreads beyond the damaged area, in hypertrophic scars it is confined to the site of the trauma. ${ }^{1-3,5}$ Many times it is almost impossible to distinguish between the two entities histologically, although in hypertrophic scars the abnormalities tend to clear up earlier. ${ }^{5}$

In recent years, various studies have clarified the mechanism by which connective tissue forms in normal and pathologic situations. ${ }^{7}$ These studies have shown that formation of scar tissue in wounds produces an increase in the lysyl-oxidase enzyme, which triggers cross-linking of the aldehyde groups derived from the lysin amino acids, thus fomenting the maturation of collagen..$^{7-9}$ This enzyme is located outside the cells along the collagen and elastin fibers, and inside the cells in fibroblasts, endothelial cells, sweat and sebaceous glands, the erector pili muscle, and in some keratinocytes. ${ }^{10}$ Concentrations of this have been found to be normal or raised in keloid and hypertrophic scars, ${ }^{11}$ and increased in some conditions which involve heightened 
collagen synthesis. ${ }^{12}$ Moreover, in keloid and hypertrophic scars other abnormalities have been detected, such as an increase in water, calcium, fibronectin, collagen type VI, and transforming growth factor (TGF)- $\beta 1$, certain enzymes such as proline hydroxylase and galactosylhydroxylysyl glucosyltransferase, and cross-linking in the collagen that is formed; a decrease in polypeptides of protocollagen as a result of an increase in degradation; and concentrations of collagenase and collagen I and III which vary in different studies. ${ }^{13}$

Bleomycin administration has proved useful in certain malignancies. ${ }^{14}$ It has also been effective in the treatment of keratoacanthomas, ${ }^{15}$ cutaneous neurofibromas, ${ }^{16}$ and recalcitrant vulgar warts. ${ }^{17}$ More recently, intradermal bleomycin injections have been shown to bring about significant improvements in keloid and hypertrophic scars. ${ }^{18}$ In this French study they treated 31 keloids and 5 hypertrophic scars with three to five intralesional infiltrations within a 1-month period. They obtained a total regression of $84 \%$. They observed that the treatment was effective in all cases within the first two infiltrations, evidenced by a reduction in the volume of keloid, a clear reduction of functional impairment in most patients. In addition, injection of bleomycin in the skin of healthy subjects has been found histologically to cause necrosis of keratinocytes with a mixed inflammatory infiltrate, together with the expression of various adhesion molecules. ${ }^{19}$ Furthermore, in common warts treated with bleomycin, apoptoic cells also appear. ${ }^{20}$ Despite these findings, however, the mechanism by which this drug acts is not entirely clear.

One of the best-known side effects of bleomycin is pulmonary, renal, and cutaneous fibrosis when the drug is administered systemically. ${ }^{21}$ This, together with the observation of scleroderma-like manifestations secondary to bleomycin, ${ }^{22}$ would seem to be in contradiction to the clinical effect observed in our patients. Studies of the mechanism of drug action in these cases have yielded contradictory results. Administration of bleomycin in rats produces an increase in protocollagen and lysyloxidase synthesis in the lungs and in fibroblasts in the dermis. ${ }^{23-26}$ But other recent studies have pointed out that in cultures of human dermal fibroblasts there is a highly significant reduction in lysyl-oxidase as a result of the action of bleomycin. ${ }^{27}$ Similarly the administration of various cytostatics such as bleomycin has been found to produce inhibition of the collagen synthesis when its effect is analyzed in cultures of human dermal fibroblasts. If TGF- $\beta 1$ is added to the culture, bleomycin also inhibits the collagen synthesis resulting from this growth factor. ${ }^{28}$

We are aware of the limitations of this study since we did not use a control group. We cannot know with any degree of certainty what mechanism caused these lesions to improve in our patients. Nevertheless, we think that improvement could be the result of a reduction in collagen synthesis and/or an increase in its destruction, or due to inhibition of lysyl-oxidase or TGF- $\beta 1$. In addition, we believe that bleomycin, administered through multiple intralesional punctures as we have described, is an effective treatment for keloid and hypertrophic scars. As Shelley and Shelley ${ }^{6}$ described in the case of common warts, this means of applying bleomycin ensures safety, as far less (probably under 5\%) penetrates through to the bloodstream than when the drug is given intradermally.

In summary, we think bleomycin may be a drug of promise in the treatment of keloids and hypertrophic scars using multiple needle puncture. Nevertheless, further studies will provide more information about the mechanism by which this drug acts in this type of lesion. 


\section{REFERENCES}

1. Rusciani L, Rossi G, Bono R. Use of cryotherapy in the treatment of keloids. J Dermatol Surg Oncol 1993;19:529-34.

2. Nemeth AJ. Keloids and hypertrophic scars. J Dermatol Surg Oncol 1993; 19:738-46.

3. Murray JC. Keloids and hypertrophic scars. Clin Dermatol 1994; 12:27-37.

4. Fitzpatrick TB. The validity and practicality of sun-reactive skin types I through VI. Arch Dermatol 1988;124:869-71.

5. Lever WF, Schaumburg-Lever G. Histopathology of the skin, 6th ed. Philadelphia: JB Lippincott, 1983:597-622.

6. Shelley WB, Shelley ED. Intralesional bleomycin sulfate therapy for warts: a novel puncture technique. Arch Dermatol 1991;127:234-6.

7. Craig RDP, Schofield JD, Jackson DS. Collagen biosynthesis in normal human skin, normal and hypertrophic scar and keloid. Eur J Clin Invest 1975;5:69-74.

8. Fushida-Takemura H, Fukuda M, Maekawa N, Chanoki M, et al. Detection of lysyl-oxidase gene expression in rat skin during wound healing. Arch Dermatol Res 1996;288:7-10.

9. Siegel RC, Fu JC, Chang Y. Collagen cross-linking: the substrate specificity of lysyl oxidase. Adv Exp Med Biol 1976;74:438-46.

10. Wakasaki H, Ooshima A. Immunohistochemical localization of lysyl oxidase in normal human skin. Br J Dermatol 1994;131:325-30.

11. Di Cesari PE, Cheung DT, Perelman N, Libaw E, Peng L, Nimni ME. Alteration of collagen composition and cross-linking in keloid tissues. Matrix 1990;10:172-8.

12. Chanoki M, Ishii M, Kobayashi H, Fushida H, et al. Increased expression of lysyl oxidase in skin with scleroderma. Br J Dermatol 1995;133:710-15.

13. Berman B, Bieley HC. Keloids. J Am Acad Dermatol 1995;33: 117-23.

14. Bennet JM, Reich SD. Bleomycin. Ann Intern Med 1979;90:945-8.

15. Sayama S, Tagami H. Treatment of keratoacanthoma with intralesional bleomycin. Br J Dermatol 1983;109:449-52.

16. Carrozzo AM, Gatti S, Marinaro C, Angelini E, Tomassoli M, Nini G. Intralesional bleomycin in the treatment of von Recklinhausen neurofibromas. Presented at the Third Congress of the European Academy of Dermatology and Venereology, Copenhagen, September 26-30, 1993, poster B101.

17. Shumer SM, O'Keefe EJ. Bleomycin in the treatment of recalcitrant warts. J Am Acad Dermatol 1983;9:91-6.

18. Bodokh Y, Brun P. Traitement des chéloïdes par infiltrations de bléomycine. Ann Dermatol Venereol 1996;123:791-4.

19. Templeton ST, Solomon AR, Swerlick RA. Intradermal bleomycin injections into normal human skin. Arch Dermatol 1994;130: 577-83.

20. James MP, Collier PM, Aherne W, Hardcastle A, Lovegrove S. Histologic, pharmacologic, and immunocytochemical effects of injection of bleomycin into viral warts. J Am Acad Dermatol 1993;28: 933-7.

21. Crooke ST, Bradner WT. Bleomycin: a review. J Med 1976;7:333-428.

22. Finch WR, Rodnan GP, Buckingham RB, Prince RK, Winkelstein A. Bleomycin-induced scleroderma. J Rheumatol 1980;7:651-9. 
23. Chandrasekaran L, Seethalakshmi S, Chandrakasan G, Dhar SC. Alterations in lung and skin compositions of rat in bleomycin-induced fibrosis. Biochem Med Metab Biol 1987;38:205-12.

24. Rao JS, Rao VH, Venkaiah B. Influence of bleomycin on the crosslinking of dermal collagen in rat. Ital J Biochem 1982;31: 114-20.

25. Reiser KM, Tryka AF, Lindenschmidt RC, Last JA, Witschi HR. Changes in collagen cross-linking in bleomycin-induced pulmonary fibrosis. J Biochem Toxicol 1986;1:83-91.

26. Clark JG, Starcher BC, Uitto J. Bleomycin-induced synthesis of type I procollagen by human lung and skin fibroblasts in culture. Biochim Biophys Acta 1980;631:359-70.

27. Yeowell HN, Marshall MK, Walker LC, Ha V, Pinnell SR. Regulation of lysyl oxidase mRNA in dermal fibroblasts from normal donors and patients with inherited connective tissue disorders. Arch Biochem Biophys 1994;308:299-305.

28. Hendricks T, Martens MF, Huyben CM, Wobbes T. Inhibition of basal and TGF beta-induced fibroblast collagen synthesis by antineoplastic agents. Implications for wound healing. Br J Cancer 1993; 67:545-50. 


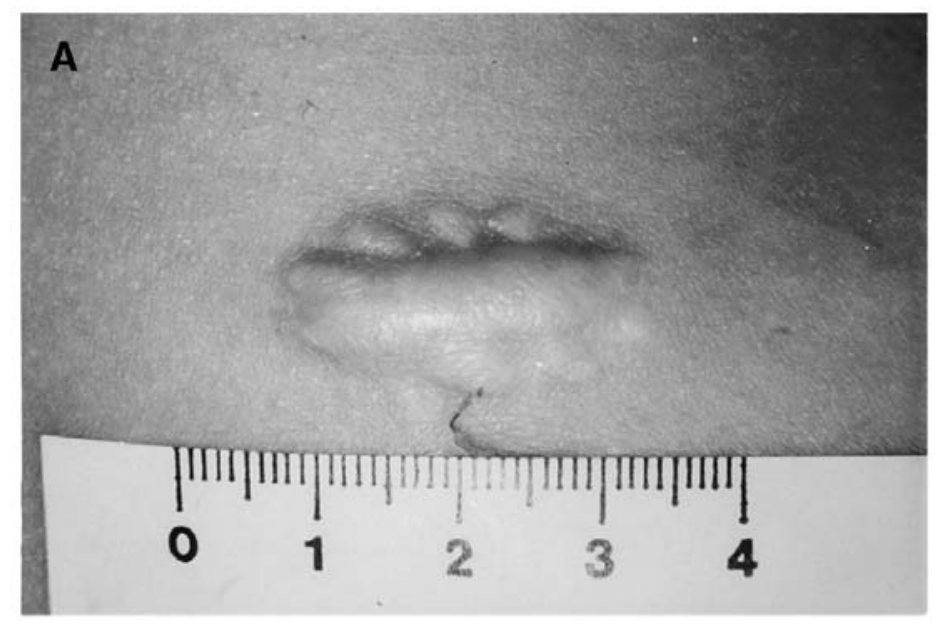

\section{B}

Figure 1. Patient 4. A) Keloid lesion on the back after extirpation of a nevus. B) Complete disappearance, with no recurrence at 11 months. 

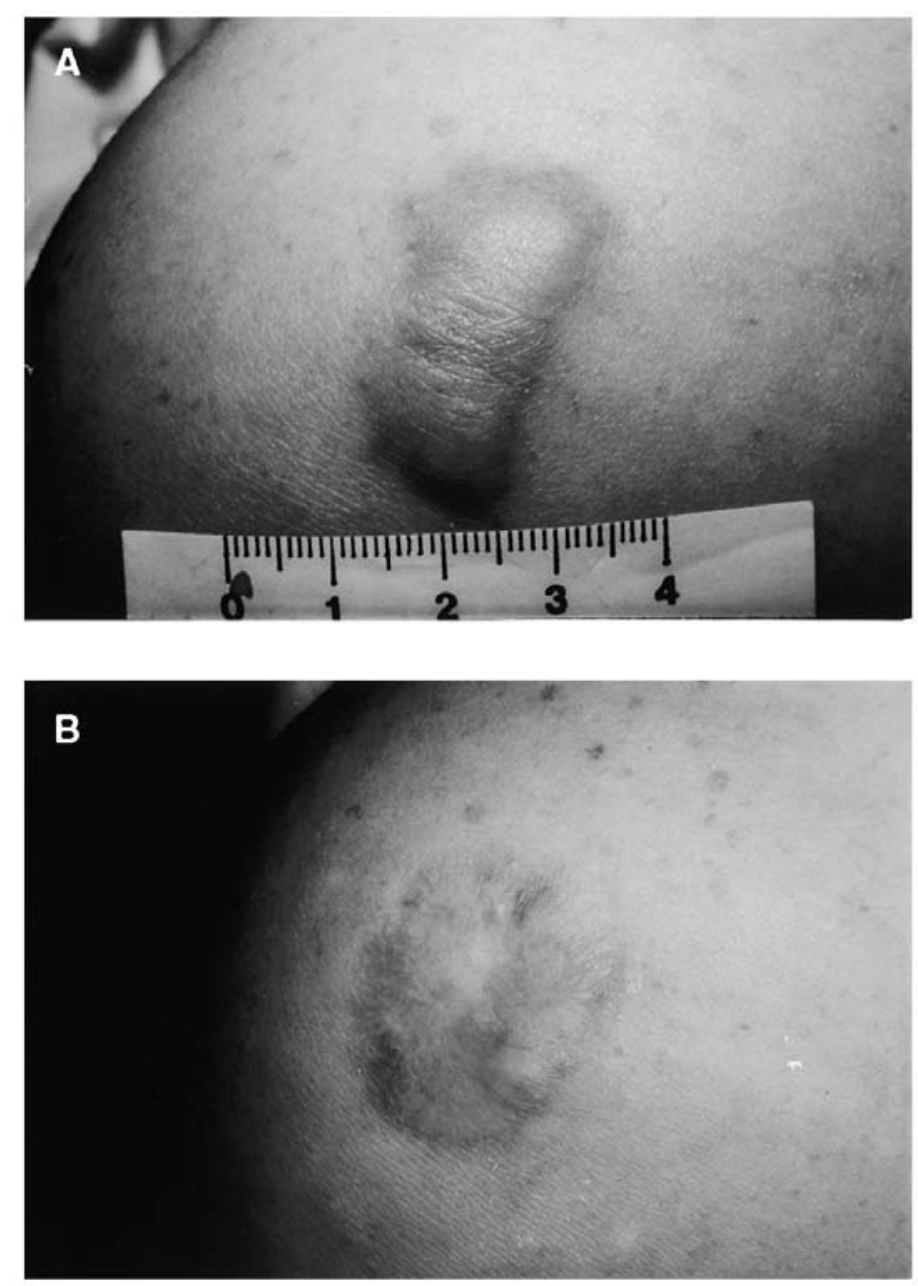

Figure 2. Patient 2. A) Keloid after vaccination in the deltoid region. B) Complete healing of the lesion, with one small recurrence (arrow) 1 year after the end of treatment. 

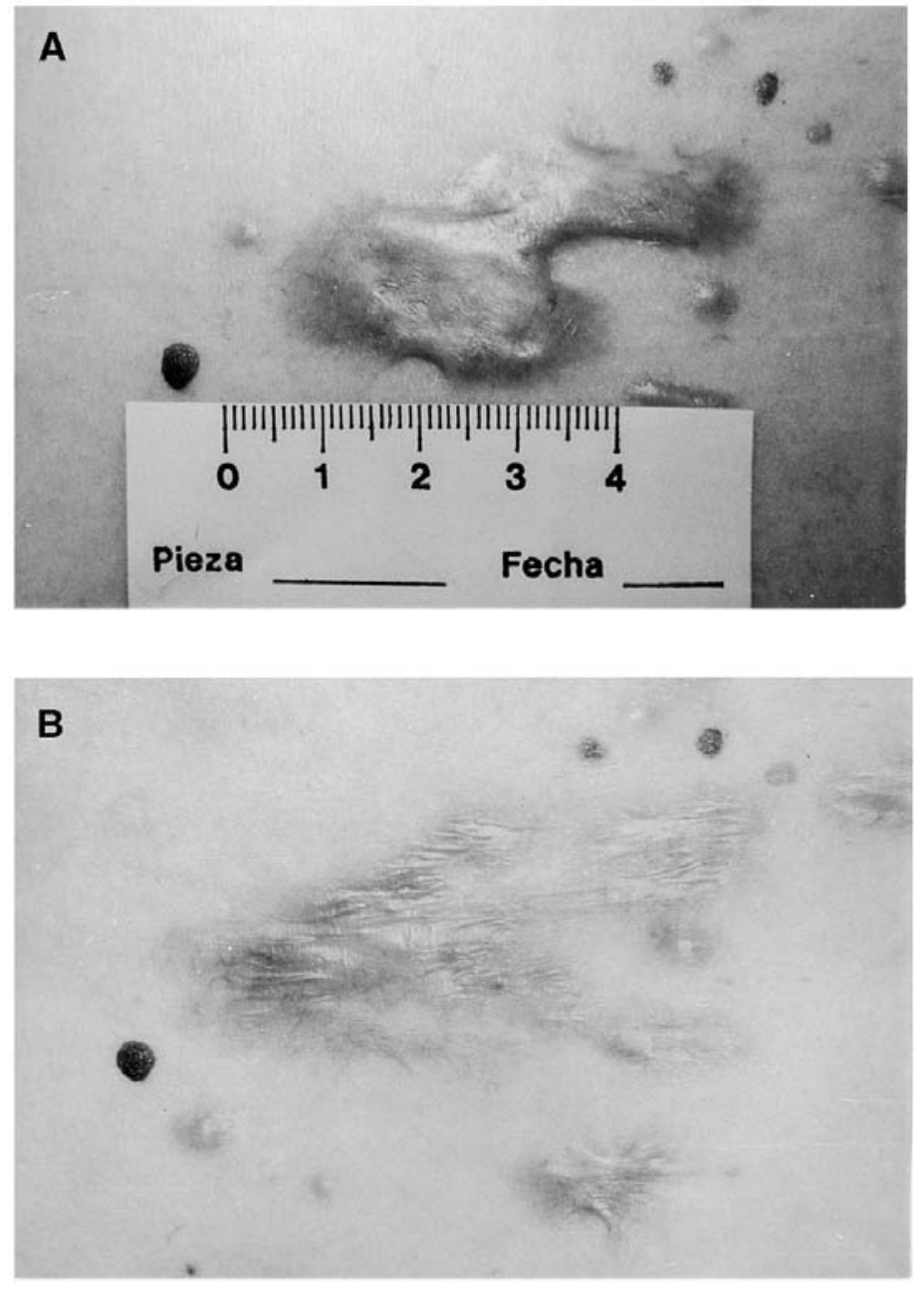

Figure 3. Patient 6. A) Multiple keloid lesions. The original lesion had been in the presternal region. B) Almost complete disappearance $(>90 \%)$. The patient remains stable at 10 months. 
Table 1. Patient Characteristics

\begin{tabular}{|c|c|c|c|c|c|c|c|c|c|c|c|c|}
\hline Patient & Sex & $\begin{array}{l}\text { Age } \\
\text { (years) }\end{array}$ & $\begin{array}{l}\text { Skin } \\
\text { type }\end{array}$ & $\begin{array}{l}\text { Type of } \\
\text { scar }\end{array}$ & Localizations & $\begin{array}{l}\text { Time of } \\
\text { course }\end{array}$ & $\begin{array}{l}\text { Treatment } \\
\text { before }\end{array}$ & $\begin{array}{c}\text { No. of } \\
\text { sessions }\end{array}$ & Trigger factor & Side effects & $\begin{array}{c}\text { Results } \\
\text { after } \\
\text { treatment }\end{array}$ & Evolution \\
\hline 1 & $\mathrm{~F}$ & 23 & II & HS & Chain & 2 months & Corticosteroids & 2 & Surgery & No & $\mathrm{CF}$ & $\begin{array}{c}\text { No lesion after } 16 \\
\text { months }\end{array}$ \\
\hline 2 & $\mathrm{~F}$ & 19 & III & $\mathrm{KL}$ & Shoulder & $\begin{array}{c}12 \\
\text { months }\end{array}$ & No treatment & 5 & Vaccination & Hyperpigmentation & $\mathrm{CF}^{\mathrm{a}}$ & $\begin{array}{c}\text { Small nodule after } \\
1 \text { year }\end{array}$ \\
\hline 3 & $\mathrm{~F}$ & 36 & III & KL & Shoulder & $\begin{array}{c}\text { Several } \\
\text { years }\end{array}$ & Corticosteroids & 3 & Vaccination & No & $\mathrm{CF}$ & $\begin{array}{c}\text { No lesion after } 3 \\
\text { years }\end{array}$ \\
\hline 4 & $\mathrm{~F}$ & 14 & III & HS & Back & 9 months & No treatment & 3 & Surgery & No & $\mathrm{CF}$ & $\begin{array}{c}\text { No lesion after } 11 \\
\text { months }\end{array}$ \\
\hline 5 & $\mathrm{~F}$ & 35 & II & HS & Shoulder & 7 months & Thiomucase & 2 & Surgery & No & $\mathrm{SF}$ & $\begin{array}{l}\text { No growing back } \\
\text { after } 8 \text { months }\end{array}$ \\
\hline 6 & $\mathrm{~F}$ & 23 & III & KL & $\begin{array}{c}\text { Multiple } \\
\text { localization }\end{array}$ & 6 years & No treatment & 2 & Spontaneous & No & HSF & $\begin{array}{l}\text { No growing back } \\
\text { after } 10 \text { months }\end{array}$ \\
\hline 7 & $\mathrm{~F}$ & 21 & II & KL & $\begin{array}{c}\text { Multiple } \\
\text { localization }\end{array}$ & 5 years & Corticosteroids & 3 & Spontaneous & No & HSF & $\begin{array}{l}\text { No growing back } \\
\text { after } 10 \text { months }\end{array}$ \\
\hline 8 & $\mathrm{M}$ & 30 & III & KL & Chest & 3 years & Silicone & 4 & Acne & Hyperpigmentation & $\mathrm{CF}^{\mathrm{a}}$ & $\begin{array}{c}\text { Small nodules } \\
\text { after } 10 \text { months }\end{array}$ \\
\hline 9 & $\mathrm{~F}$ & 27 & III & $\mathrm{KL}$ & $\begin{array}{c}\text { Multiple } \\
\text { localization }\end{array}$ & $\begin{array}{c}\text { Several } \\
\text { years }\end{array}$ & Corticosteroids & 4 & Spontaneous & No & HSF & $\begin{array}{c}\text { No lesion after } 5 \\
\text { months }\end{array}$ \\
\hline 10 & $\mathrm{~F}$ & 27 & II & HS & Chest & 6 months & No treatment & 2 & Surgery & No & HSF & $\begin{array}{c}\text { No lesion after } 2 \\
\text { years }\end{array}$ \\
\hline 11 & $\mathrm{~F}$ & 18 & III & HS & Chest & 5 months & No treatment & 1 & Surgery & No & $\mathrm{CF}$ & $\begin{array}{c}\text { No lesion after } 13 \\
\text { months }\end{array}$ \\
\hline 12 & $\mathrm{M}$ & 17 & III & KL & $\begin{array}{c}\text { Multiple } \\
\text { localization }\end{array}$ & $\begin{array}{c}12 \\
\text { months }\end{array}$ & No treatment & 2 & Acne & No & HSF & $\begin{array}{l}\text { No growing back } \\
\text { after } 7 \text { months }\end{array}$ \\
\hline 13 & $\mathrm{M}$ & 20 & III & HS & Face & 2 years & No treatment & 3 & Cut & No & $\mathrm{CF}$ & $\begin{array}{c}\text { No lesion after } 1 \\
\text { year }\end{array}$ \\
\hline
\end{tabular}

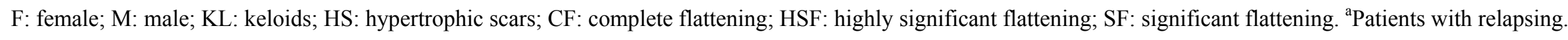

